NBER WORKING PAPER SERIES

\title{
ENDOGENOUS GROWTH, PUBLIC \\ CAPITAL, AND THE CONVERGENCE OF \\ REGIONAL MANUFACTURING INDUSTRIES
}

Charles R. Hulten

Robert M. Schwab

Working Paper No. 4538

\section{NATIONAL BUREAU OF ECONOMIC RESEARCH \\ 1050 Massachusetts Avenue \\ Cambridge, MA 02138 \\ November, 1993}

We thank the National Science Foundation for its support of this research, and Michael Svilar and Andrew Kochera for their excellent work as our research assistants. We also thank Alicia Munnell for providing us with her data on public capital, and Douglas Holtz-Eakin and Dale W. Jorgenson for their valuable comments. This paper is part of NBER's research program in Productivity. Any opinions expressed are those of the authors and not those of the National Bureau of Economic Research. 


\title{
ENDOGENOUS GROWTH, PUBLIC \\ CAPITAL, AND THE CONVERGENCE OF \\ REGIONAL MANUFACTURING INDUSTRIES
}

\begin{abstract}
Several explanations can be offered for the unbalanced growth of U.S. regional manufacturing industries in the decades after World War II. The convergence hypothesis suggests that the success of the South in catching up to the Northeast and Midwest should be understood by analogy with the economic success of Japan and the rest of the G-7 in closing the gap relative to the U.S. as a whole. Endogenous growth theory, on the other hand, assigns a central role to capital formation, broadly defined. A variant of endogenous growth theory focuses on investments in public infrastructure as a key determinant of regional growth. Finally, traditional location theory stresses the evolution of regional supply and demand and the role of economies of scale and agglomeration.

This paper compares these altemative explanations of U.S. regional growth by testing their predictions about the productive efficiency of regional manufacturing industries. We find little evidence that technological convergence explains the regional evolution of U.S. manufacturing industry, or that endogenous growth was an important factor. We also find little evidence that public capital externalities played a significant role in explaining the relative success of industries in the South and West. The main engine of differential regional manufacturing growth over the period $1970-86$ seems to be inter-regional flows of capital and labor. The growth of multifactor productivity is essentially uniform across regions, although there is some variation in the initial levels of efficiency.

Charles R. Hulten

Department of Economics

University of Maryland

Tydings Hall

College Park, MD 20742

and NBER

Robert M. Schwab Department of Economics University of Maryland Tydings Hall College Park, MD 20742
\end{abstract}




\section{Introduction}

The Amerlcan South started the post World War II era as the poorest region of the country. Per caplta disposable income was less than 70 percent of the national level and the South produced less than 13 percent of national manufacturing output at that time. However, during the ensuing 40 years, the South grew much faster than the most of the rest of the nation. As a result, Incomes in the South are now 90 percent of the national average and the South now produces 22 percent of all manufacturing output.

Several explanations have been offered for this pattern of unbalanced reglonal growth. The convergence hypothesis postulates an inverse relationship between the rate of economic growth and the initial level of economic activity (Barro and Sala-1-Martin 1991, Holtz-Eakin 1991). In this view of growth, backwardness per se implies a potential advantage that can allow lagging reglons to catch up to the leaders. Applled to the U.S., the convergence hypothesis suggests that the success of the U.S. South in catching up to the Northeast and Midwest should be understood by analogy w1th the economic success of Japan and the rest of the G-7 in closing the gap relative to the U.S. as a whole.

Endogenous growth theory, on the other hand, assigns a central role to capital formation, whlch is broadly deflned to include physical, human, Infrastructure, and knowledge capltal. ${ }^{2}$ The rate of growth of any region depends on the rate of time preference relative to the marginal productivity of capital, which is assumed to exhlblt constant returns to scale instead of diminishing returns as in prevlous neoclasslcal models. The larger the wedge between the time rate of discount and the return to Investment, the more rapid 
the rate of growth. When applied to U.S. regional growth, this framework suggests that the lagging economic performance of the South was due to Inadequate capital formation, and the subsequent boom to an increase in the rate of investment. The work of Garcia-Mila and McGuire (1987), Aschauer (1989), Munnell (1990), and Morrison and Schwartz (1992) focuses particular attention on the role of public investment as a determinant of U.S. regional growth performance.

In contrast to these two explanations, traditional location theory stresses the evolution of reglonal supply and demand and the role of economies of scale and agglomeration, comblned with nation-wide factors like technological change, aggregate savings, and population growth, as the determinant of regional location and growth. The recent paper by Krugman (1991) shows that the location of manufacturing activity can be concentrated or dispersed among reglons depending on the relative strengths of scale economies, regional demand, and transport costs.

This paper compares these alternative explanations of U.S. reglonal growth by testing their predictions about the productive efficiency of reglonal manufacturing industries. ${ }^{3}$ Using $1970-1986$ data from the Census and Annual Survey of Manufactures for the nine Census divisions of the U.S. and national data from the Bureau of Labor Statistics and Bureau of Economic Analysis, we estimate the level of multifactor productivity (MFP) in each region. We then test for technological convergence and endogenous growth effects assoclated with infrastructure externalities and increasing returns to reproducible inputs, against the prediction of conventional regional theory that the growth rates of technical efficlency are the same across regions 
(1.e., that any differences in efflclency levels are region-speclfic and constant over time). This test has the collateral effect of addressing the actively debated question of whether or not publlc capital has a strong 1 mpact on manufacturing productivity.

\section{Testing the Alternative Models}

Our tests of the competing theorles are derived from the assumption that there is a Hicks-neutral production function for manufacturing industry within each 'region. We assume that manufactured goods in region $i$ in year $t, Q_{1 t}$, are produced using privately owned capital $K_{1 t}$, labor $L_{1 t}$, intermediate Inputs $M_{1 t}$, and public capital $B_{1 t}$ :

$$
Q_{i t}=A_{10} B_{1 t}^{r_{1}} e^{\lambda_{1} t} \cdot F^{1}\left[K_{1 t}, L_{i t}, M_{1 t}, B_{1 t}\right] .
$$

Our specification of the public capltal varlable follows Meade (1952) and Berndt and Hansson (1991) in Identifying two ways that public capltal Influences output. First, it ylelds direct productive services and thus appears as an argument of $F^{1}[\cdot]$ (as, for example, when trucks and drivers are combined with public highways to produce transportation services). Second, public capital acts as an "environmental" factor or "systems splllover" which enhances the productivity of some or all of the private inputs. Thus $B_{i t}$ appears as an argument of the technical efflciency term in constant elasticity 
form. where the parameter $\gamma_{1}$ measures the strength of the within region splllover effect. Thls formulation of (1) also assumes that the splllover effect is separable from the pure technlcal effect, as represented by the parameter $\lambda_{1}$. $A_{10}$ is the index of the level of reglonal productive efficlency in the base year 0.4

\section{A. Technologlcal Convergence}

One varlant of the convergence model stresses the importance of technological diffusion. The model of Dowrlck and Nguyen (1989) assumes that nations with low levels of technlcal efflclency can, at some polnt in their history, become open to outside technological possibllities and can thus approprlate the exlsting technologies of advanced countrles at a faster rate than the advanced nations can develop new technology. This mechanlsm is found by Dowrlck and Nguyen to be an important source of cross-national growth differentlals. Applied to regional growth within the U.S., this varlant of the convergence model assumes that technological backwardness is an 1 mportant source of lagging economic performance, and focuses on diffusion of technology as a process through whlch reglonal disparlties are reduced or ellminated.

The technological convergence formulation assumes that reglonal technologles exhlblt inltial differences in the level of technlcal efficlency In some base year, $A_{10}$, and that the gap between the level of efflclency in any region 1 and the level of technlcal efflclency in the most advanced reglon, $A_{O t}$, closes with a speed of convergence $\theta$ : 


$$
\ln A_{1 t}-\ln A_{10}=\left(1-\left(1-\theta_{1}\right) t\right)\left(\ln A_{0 t}-\ln A_{10}\right)
$$

In (2), the growth rate of $A_{1 t}$ exceeds that of the leader, but the two converge over time. This provides the lagging region with an extra impetus to output growth.

If the pattern of reglonal growth is influenced by (2), we should observe that regional rates of technical change. $\lambda_{i}$, estimated from (1) should vary Inversely across reglons according to the initial level of efficlency, $A_{10}$. On the other hand. If the $\lambda_{1}$ do not vary across regions there is no possiblilty of convergence and elther the $\theta_{1}$ must be zero or the initial levels $A_{10}$ must be equal. In elther case, technological convergence cannot be adduced as an explanation of regional growth differentials in U.S. manufacturing industry. 5

\section{B. Endogenous Growth Models}

The endogenous growth literature has two princlpal branches: the "AK" model developed by Rebelo (1991) and the externallty-increasing returns model of Romer (1986) and Lucas (1988). Both emphasize the importance of increasing returns to scale generated by reproduclble capital inputs and both predict nonconvergent rates of growth. In the "AK" model, constant returns to capital input is Imposed directly and growth differentlals depend on the wedge between the marginal product of capital $A_{1}$ and the rate of time discount $\rho_{1}$. To explain reglonal growth patterns, each region must be treated as a separate economy with its own $A_{1}$ and $\rho_{1}$. Regional differences in marginal products may 
occur because of locational advantages, differences in region specific capital, or region specific externalities generated by capital. Regional differences in the propensity to invest that are driven by differences in the propensity to save $\left(\rho_{1}\right)$ are more difficult to rationalize in an economy which is open to capltal flows, but this is a problem common to many growth models, Including Solow-type convergence models.

The Rebelo-Romer-Lucas mechan1sm of endogenous growth theory is based on constant marglnal returns to capltal generated by capltal related splllovers. This may occur because of "within-reglon" externalitles or, following Barro (1990) and Barro and Sala 1 Martin (1992), because public capital is flxed by policy at a constant fraction of the private capltal stock, $1 . e, B_{i t}=\tau_{1}$ $K_{1 t}$. In this last case, the Romer-Lucas production function might be written as

$$
Q_{1 t}=A_{10}\left[B_{1 t}{ }^{\gamma_{1}}\right] k_{1 t}^{\alpha_{1}}{ }_{L_{1 t}^{\beta_{1}}}^{\beta_{10}}=A_{10} \tau_{1} k_{1 t}^{\alpha_{1}+\gamma_{1}}{ }_{L_{1 t}}^{\beta_{i}}
$$

If $\alpha_{i}+\beta_{1}$ equals one, private producers percelve that production takes place under constant returns to scale and a competitive equilibrium may be established. However, because public capital enhances production and because it is proportional to private capital, the true elasticity of output with respect to capltal is $\alpha_{1}+\gamma_{1}$, and there are Increasing returns to scale (the further restriction $\alpha_{1}+\gamma_{1}=1$ ylelds the "AK" model).

The endogenous growth formulation of technology (3) is clearly a special case of the production function (1), in which $F^{1}(\cdot)$ has the Cobb-Douglas form. disembodied technical change $\lambda_{i}$ is zero, and the direct and indirect effects 
of public capital are collapsed into the parameter $\boldsymbol{\gamma}_{1}$. Public capltal enters the production function of manufacturing industries mainly as a service purchased from other sectors (e.g., transportation services are reflected in $\left.M_{1 t}\right)$, and thus the direct contribution of $B_{1 t}$ is of minor importance. ${ }^{6}$ in this case, tests of the parameter $\gamma_{1}$ are equlvalent to tests of the endogenous growth model, in confunction with tests of increasing returns to scale.

\section{Location Theory}

Location theory does not have the kind of analytical unity that characterlzes the two convergence and endogenous growth hypotheses (see, for example, Krugman 1993). It is hard to formalize a parametric test of "the theory," so we wlll only observe that location models typlcally put more emphasis on regional or spatial factors, increasing returns to scale (1.e., agglomeration economies), etc. There is no reliance on reglonal differences in technology as an explanation of growth differentials except. perhaps, those introduced by differences in industry mix across regions. This leads to the expectation that the manufacturing production function for each region should have the same degree of technical efficiency, or $A_{0 t}=A_{1 t}=\ldots$ $=A_{N t}$ in each year $t$. We can test this hypothesis using the parameters of (1). since a common technology implies $A_{00}=A_{10}=\ldots=A_{\text {NO }}$ and the equality of the technical change parameters, $\lambda_{1}$. And, as shown below, we can also test for increasing returns to scale. 
Since our tests of the competing models primarlly involve the efficlency term in the production function. It is unnecessary to estimate all of the parameters of the structure of production. Instead, the relevant tests can be based on a two stage procedure that makes use of nonparametric index number techniques. The first step involves the computation of the Solow residual under the assumption that public capltal has no effect on private output growth. ${ }^{7}$ The continuous time version of the solow residual has the form:

$$
\hat{A}_{i t}^{S}=\hat{Q}_{1 t}-\pi_{1 t}^{K} \hat{K}_{1 t}-\pi_{1 t}^{L} \hat{L}_{i t}-\pi_{i t}^{M} \hat{M}_{1 t} .
$$

where hats over varlables denote rates of growth and the $\pi_{1 t}$ are income shares.

In practice, the rate of productivity growth is estimated by replacing logarlthmic differentials with differences in successive logarlthms and using average shares:

$$
\begin{aligned}
\ln A_{i t}^{S}-\ln A_{i t-1}^{S}= & \ln Q_{i t}-\ln Q_{1 t-1} \\
& -1 / 2\left(\pi_{i t}^{K}+\pi_{i t-1}^{K}\right)\left(\ln K_{1 t}-\ln K_{1 t-1}\right) \\
& -1 / 2\left(\pi_{i t}^{L}+\pi_{i t-1}^{L}\right)\left(\ln L_{i t}-\ln L_{i t-1}\right) \\
& -1 / 2\left(\pi_{i t}^{M}+\pi_{i t-1}^{M}\right)\left(\ln M_{i t}-\ln M_{i t-1}\right) .
\end{aligned}
$$

This approximation places only weak restrictions on the functional form of the underlying production function (Diewert 1976) and, in particular, is not 
restricted to the Cobb-Douglas form. However, Hicks-neutral technical change is assumed (Hulten 1973). Each term in (5), except the growth rate of the Solow residual, can in princlple be measured directly, and the growth rate of the technology index can thus be estimated as a residual.

Jorgenson and Nishimizu (1978), Denny, Fuss, and May (1981), and

Christensen, Cummings, and Jorgenson (1981) have shown that this sources of growth model can be extended to estimate differences in the level of productivity across reglons or countries. In their framework, the difference between the level of technology in region 1 at $t$ ime $t$ and region $j$ at $t$ ime $s$ equals the logarlthmic differences in output minus the share weighted logarithmic differences in inputs, where the shares are the simple averages of the shares in the two regions. Thus the level index analog to (5) is

$$
\begin{aligned}
\ln A_{1 t}^{S}-\ln A_{j s}^{S}= & \ln Q_{1 t}-\ln Q_{j s} \\
& -1 / 2\left(\pi_{1 t}^{K}+\pi_{j s}^{K}\right)\left(\ln K_{1 t}-\ln K_{j s}\right) \\
& -1 / 2\left(\pi_{1 t}^{L}+\pi_{j s}^{L}\right)\left(\ln L_{1 t}-\ln L_{j s}\right) \\
& -1 / 2\left(\pi_{1 t}^{M}+\pi_{j s}^{M}\right)\left(\ln M_{1 t}-\ln M_{j s}\right) .
\end{aligned}
$$

The resulting levels indexes, $A_{i t}^{S}$, are expressed relative to the efficiency of the "base" region in the base year, $A_{00}^{S}=1$. We have used the U.S total and 1970 as the base region and year, and thus all of the productivity index numbers should be interpreted as a proportion of national productivity in $1970 .^{8}$

After calculating the regional Solow level index numbers using equation (6), we then link measured productivity to the technlcal efficiency terms in 
the underlying production function (1) in the second stage of the analysis. The true growth rate of efflclency is derlved from (1) and equals

$$
\hat{A}_{1 t}=\gamma_{1} \hat{B}_{1 t}+\lambda_{1} t=\hat{Q}_{1 t}-\varepsilon_{1 t}^{K} \hat{K}_{1 t}-\varepsilon_{1 t}^{1} \hat{L}_{1 t}-\varepsilon_{1 t}^{M} \hat{M}_{1 t}-\varepsilon_{1 t}^{B} \hat{B}_{1 t} .
$$

where is $\varepsilon_{1 t}^{X}$ is the elasticlty of output with respect to input $X$.

A comparison of the Solow residual $\hat{A}_{1 \mathrm{t}}^{S}$ with the true efflclency term $\hat{A}_{1 t}$ reveals that public capltal's contribution to output has been 1gnored and that the income shares $\pi_{1 t}^{X}$ are assumed equal to the corresponding output elasticities $\varepsilon_{1 t}^{X}$. Th1s second assumption does not pose a problem for Income shares of the varlable private factors (labor and intermedlate input) when the economy is in competitive equillbrium and they are paid the value of their marginal products. However, it is not true that $\varepsilon_{i t}^{K}=\pi_{i t}^{K}$ in general even under competitlve assumptions. The problem arlses because the price of capltal services, $P_{1 t}^{K}$, can rarely be observed directly. Therefore, capital Income 1s usually Imputed from the "adding-up" condition that factor payments exhaust total income, with capltal income measured as the residual. The residual measurement of capltal income therefore Imposes the condition that income shares sum to one (1.e., $\left.\pi_{1 t}^{K}=1-\pi_{1 t}^{L}-\pi_{1 t}^{M}\right)$. Thus whenever the elastlclty of scale of private inputs $\varepsilon_{1 t}=\varepsilon_{1 t}^{K}+\varepsilon_{1 t}^{L}+\varepsilon_{1 t}^{M}$ is different from one, $\pi_{1 \mathrm{t}}^{K}$ misstates capltal's true output elasticity.

These varlous sources of blas can, however, be accounted for explicltiy to yield an exact relation between the growth rate of the Solow resldual and the true efflciency term. WIth some manlpulation, 1 t can be shown that 


$$
\hat{A}_{1 t}^{S}=\lambda_{1 t}+\left(\gamma_{1 t}+\varepsilon_{1 t}^{B}\right) \hat{B}_{1 t}+\left[\varepsilon_{1 t}-1\right) \hat{K}_{1 t} .
$$

where $\varepsilon_{1 t}$ is the scale elasticity. This expression indicates that the growth rate of the measured Solow residual is the sum of three factors: (1) the rate of growth of public capital welghted by the indirect and direct contributions of public capital, (11) the growth rate of private capital welghted by a correction for any error that is introduced by the assumption of constant returns to scale in private inputs, and (111) the true growth rate of technical progress.

Equation ( 8 ) relates the growth of the Solow residual to its component elements and forms the emplrical basis for our test of the varlous theorles of regional growth (varlants of (8) are also the basis for the marginal cost mark-up model of Hall (1988) and the externality model of Caballero and Lyons (1990a, 1990b). However, since the convergence hypothesis involves the level of technical efficlency rather than its growth rate, one final step is needed to complete the second stage our analysis. By assuming that $\gamma_{1}, \varepsilon_{1}^{B}, \varepsilon_{1}$, and $\lambda_{i}$ are constant over time, we can integrate (8) over time to obtain 9

(9) $\ln A_{1 t}^{S}=\ln A_{10}+\lambda_{1} t+\left[\gamma_{1}+\varepsilon_{1}^{B}\right] \ln B_{1 t}+\left[\varepsilon_{i}-1\right] \ln K_{1 t}$.

The various hypotheses discussed above are special cases of this equation, and we will therefore use the stochastic version of (9) in the emplrical work presented below. 10 


\section{Data}

The data needed to estimate the parameters of equation (9) are described in full in our earller papers (Hulten and Schwab 1984, 1991). Our analysis is restricted to manufacturing industries. Most of our regional data were obtalned from the Census of Manufactures and the Annual Survey of Manufactures and then reconclled to Bureau of Labor Statistics totals. We use gross output as our measure of output in this paper, and thus our private inputs include capital, labor, and intermediate inputs (corrected for the purchased services problem). Since regional output deflators are not avallable from any source, we have used the national deflators from the U.S. Bureau of Labor Statistics. This introduces a potential bias in our results, since any error in the price deflator translates directly into an error in measuring real output and thus into an error in measuring the left hand side of (9). 11

Our data on public capltal are the same as those used in Munnell (1990); a full description of the data are included in Appendix A of that paper. Briefly, Munnell used annual data on state capital outlays to allocate BEA estimates of the national stock of public capital among the states. Her data set includes estimates of total public capltal for each state as well as separate estimates of state stocks of highways and water and sewer facilities. Since the Munnell data are avallable only for the period 1970-1986, our analysis is $11 \mathrm{mited}$ to those years.

Table 1 presents summary statistics on our measures of manufacturing input, output, and the Solow residual. Table I also includes summary statistics on regional output per worker, capital per worker, and public 
capital. It is clear from this table that the manufacturing sector grew much faster in the South and West. Gross output rose 3.75 percent per year in the Sun Belt during the 1970-1986 perlod as compared to only 1.53 percent per year in the Snow Belt. ${ }^{12}$ Labor input grew by more than 1 percent per year in the Sun Belt but fell in the Snow Belt. Public capital grew more rapidly in the Sun Belt (2.09 versus 1.30 percent).

It is highly slgniflcant for our subsequent analysis that the differential grow rates of reglonal output were due almost entirely to the differential growth in inputs. Reglonal differences in the growth rates of the Solow residual (MFP) were relatively small, with the Snow Belt actually enjoying a slight advantage over the Sun Belt (1.41 percent per year versus 1.23). It was also the case that the level of MFP in the varlous regions of the country were very similar at the beginning and end of our sample period. It is also clear that the growth rates of capital per worker and output per worker were roughly the same in the Sun Belt and Snow Belt regions over this perlod. Our conclusions about MFP convergence during the years 1970-1986 can thus be extended to the convergence in output per worker due to capital-deepening. Our data would thus suggest a theory of regional economic growth that stressed the cross-sectional equality of productivity, prior to any econometric analysis.

This impression is reinforced by decomposing the total varlation of MFP into variation across time within in regions and varlation across regions. Slightly less than one-half of the the varlation in the level of MFP is due to cross sectional variation, with the balance due to variation over time. For the growth rates of MFP, however, virtually all of the varlation is varlation 
over $t$ ime, i.e.there is almost no varlation in the growth rate of MFP across regions. Given the substantial differences in the growth rates of public capltal stock in different reglons, the lack of varlation in the growth rate of MFP suggests that the two varlables are essentially uncorrelated.

Table 1 covers a falrly short perlod 1970-1986, and 1 t is possible that convergence ( 1 n terms of MFP or capltal per worker) was essentlally complete by that time. Regional gross output data are not avallable prior to the mid-1960s, but regional value added data are avallable beginning in 1951 . In Table 2, we briefly shift the focus to value added as a measure of output in order to extend the analysis back in time. That table indicates that there has been no significant compression (or divergence) in MFP, in output per worker, or in capital-deepening since 1951.

\section{Econometric Results 1: Hypothesis Tests of Competing Models}

While the data shown in Tables 1 and 2 are suggestive, they do not constitute a formal test of the alternative hypotheses about regional growth. An econometric test can, however, be obtalned by estimating the parameters of the system of nine linear equations, each relating the natural logarithms of the level of reglonal MFP to a constant, the natural log of private capital in the region, the natural log of public capltal and time. In other words, we implement the model (9) without any parameter restrictions across equations Moreover, since we use index number procedures to account direct inputs of capital and labor, we impose no restrictions on the form of $F^{\dot{1}}(\cdot)$. Our paper 
thus differs from much of the other econometric literature on reglonal growth, In which parameters are constralned to be equal across regions, except possibly for reglonal flxed effects. Indeed, one of our objectives is to test the validlty of the cross-reglonal parameter restrlctions which we have shown to be tests of the alternative theorles of growth discussed above.

The nesting scheme of the various cross-equation restrictions is shown in Figure 1. The box at the top level represents the case in which the system (9) is estimated without any parameter restrictions (designated $R_{0}$ ). The four boxes on the next line represent, respectively, the equality restrictions on each of four sets of parameters (designated $R_{1}, R_{2}, R_{3}, R_{4}$ ). $R_{1}$ tests for the equality across regions of the intercept of the MFP regressions allowing all other parameters to vary, and thereby tests for equality of initial MFP levels among the regions. Simllarly, the restrictions in $R_{2}$ test for the equality of the regional growth rates of technical change (the coefficients on $t$ ). If this restriction cannot be rejected, we cannot reject the hypothesis that regional technical change exhibits nelther convergence nor divergence. $R_{3}$ and $\mathrm{R}_{4}$ test whether the MFP elasticity of public capital and the scale elasticity of private inputs are zero in all regions, and thus test for endogenous growth effects associated with public and private capital, respectively (1.e., test for the importance of public capital externalities and increasing returns to scale in private inputs).

The boxes on the third level test whether the restrictions on the second level can be imposed jointly, two at a time. There are six possibilities for these pair wise restrictions: $R_{12}$ ' the initial levels of MFP are equal $\left(R_{1}\right)$ and the growth rates of technical change are also equal $\left(R_{2}\right)$, letting the 


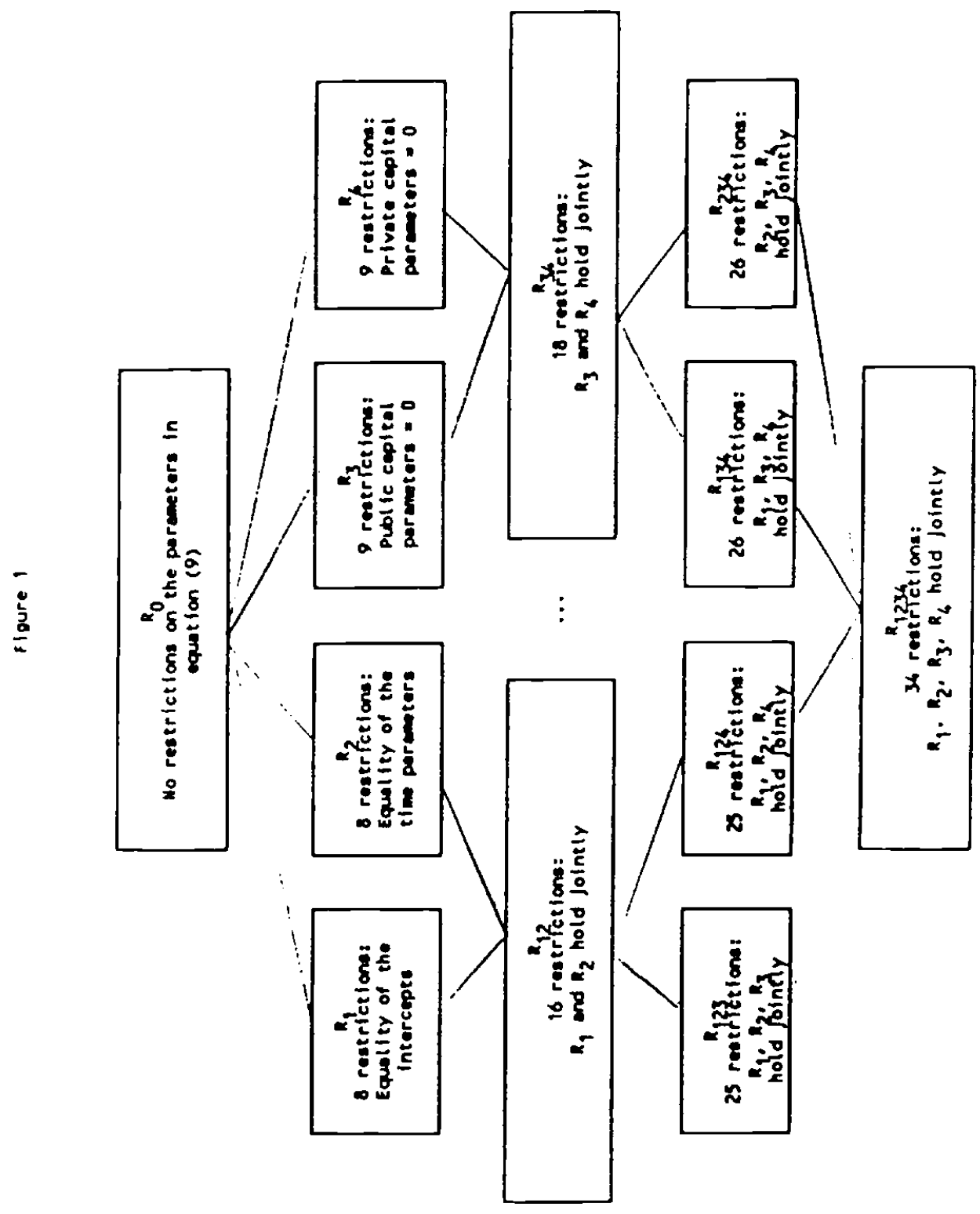


other parameters vary freely across reglons; $R_{13}$, the Initial levels of MFP are equal $\left(R_{1}\right)$ and the elasticity of MFP with respect to public capital are also equal $\left(R_{3}\right)$; and so on for $R_{14}, R_{23}, R_{24}$, and $R_{34}$. Only the boxes for $R_{12}$ and $R_{34}$ are shown in Figure 1, for ease of exposition, but these are also the joint hypotheses of particular interest, since the restrictions of $R_{12}$ Imply identical regional paths for technical change and $R_{34}$ imply that there are no endogenous growth effects linked to public or private capital.

The four boxes on the fourth line of Figure 1 show the possible combinations in which three of the four restrictions hold jointly (they are designated $R_{123}, R_{134}, R_{124}$, and $R_{234}$ ). Finally, $R_{1234}$ on the bottom level is a test of all the restrictions simultaneously. If all of the restrictions hold jointly, the regional paths of MFP are identical and are not influenced by the amount of public capital in each region, nor by increasing returns to scale effects. This situation is, of course, very unfavorable to the convergence and endogenous growth explanations of the evolution of reglonal manufacturing industry in the U.S.

Table 3 presents the sum of squared errors and F statistics associated with the various possible restrictions. It is apparent from this table that the data do not reject (at the 1 or 5 percent levels of significance) any of the restrictions imposed by themselves. If, for example, the public capital parameter, $\gamma_{1}$, is constrained to be zero in each region, the resulting model, (9') $\quad \ln A_{i t}^{S}=\ln A_{i 0}+\lambda_{i} t+\left[\varepsilon_{i}-1\right] \ln K_{i t}$, cannot be distingulshed from the original (9). Similarly. Table 3 indicates 
that, mutat Is mutand1, a model that makes $A_{10}$ or $\lambda_{1}$ the same across reglons, or makes $\left(\varepsilon_{1}-1\right)$ zero, cannot be distingulshed from (9). Further, the data do not reject any of the pairs of restrictions imposed jointly. It is only when the fourth level of three-way restrictions is reached that one set of restrictions. $R_{134}$ ' is rejected; the data do not accept the simultaneous equality of the initlal levels of MFP, a zero elasticlty of MFP with respect to public capital, and constant returns to the private inputs, implying that the model $\ln A_{1 t}^{S}=\ln A_{0}+\lambda_{1} t$ is not a valid model. However, all of the other three-way restriction do hold jolntly. Finally, the simultaneous Imposition of all restrictions simultaneously, $R_{1234}$. is also rejected, so that $\ln A_{1 t}^{S}=\ln A_{0}+\lambda t$ is not an appropriate model. 13

Table 3 thus provides very little good news for the convergence or endogenous growth explanations of regional manufacturing growth. The predictions of these models simply do not dominate other explanations in which convergence and endogenous growth play no role.

\section{Econometric Results II: Estimation of Restricted Models}

The results presented in Table 3 are compared with a base-line assumption that all parameters, Including the elasticities of MFP with respect to public and private capital, vary across regions. In this section we approach the problem from a slightly different point of view by restricting the elasticities of public and private capital to be equal across regions. This 
is consistent with the recent literature on reglonal growth (e.g., Holtz-Eakin 1992, Garcla-Mila, McGulre, and Porter 1993, Munnell 1990, and Aschaver 1990) This shift in perspective make it easier to compare our results to other recent research. Moreover, because there are so many parameters in the unrestricted version of the models in the previous section, it is hard to estimate any particular parameter precisely and to interpret the resulting coefficients. Finally, restricting the elasticities to be equal across reglons is consistent with the data. As shown in Table 3, we cannot reject the hypothesis that all of the elasticities with respect to public and private capital are equal to zero, and thus we certalnly cannot reject the hypothesis that they are all equal to one another.

The results of this alternative approach are shown in Table 4 . The first column of Table 4 reports the results obtained from the estlmation of the most constrained version of these models where the initial level of MFP and the growth rate of MFP are all assumed to be equal across reglons. Interestingly, the results are similar to those found in the earlier literature on public capital: the coefficlent on public capltal is statistlcally signiflcant and reasonably large given that the direct effect of public capital is already accounted for in the purchased service component of $F^{1}(\cdot)$. The private capital coefficlent suggests that there are mildly decreasing returns to scale and the point estimate of the time parameter implies a rate of MFP growth of 0.8 percent per year.

It is common in this literature to include a measure of capacity utilization in order to control for the cyclical effect of demand fluctuations on the Solow residual. Many, however, view this practice with some 
skepticlsm. As Berndt and Fuss (1986) and Hulten (1986) show, there is no theoretical justiflcation for including capacity utllization in a productivity model since the effects of the business cycle should be reflected in the output elasticity of private capital. Capacity utilization is particularly problematical in reglonal studies since reglonal capaclty ut 11 ization measures are not avallable.

Setting these concerns aside for the moment, column (5) in Table 4 adds the Federal Reserve Board's national capacity utllization data for manufacturing to the model in column (1). As shown in column (5), when we add capacity utilization the plcture does not change very much, though the error sum of squares does fall significantly.

Reglonal fixed effects are introduced in column (2) by allowing for separate regional intercepts (New England is taken as the base region). As in previous studies, the addition of these reglonal flxed effects causes the public capital varlable to become statistically insignificant (and negative as well). The same is true for private capital, implying constant returns to scale. Five of the reglonal intercepts are slgnificant at conventional levels, and the rest are marginally signlficant at low levels. Adding capacity utilization does not change this plcture, except to reduce the sum of squared errors and lmprove the significance of the reglonal intercepts.

Column (3) allows for reglonal time effects while holding the intercepts the same for all reglons (1.e., we Impose a common level of MFP at the outset to see if the times paths of MFP diverge). We find that this ylelds a larger estimate of the public capltal coefficlent than the base case of column (1), and that it implies strongly decreasing returns to scale. Half of the 
reglonal time effects are significant. As before, adding capacity utillzation does not change the results.

The last step taken in Table 4 is to go beyond the fixed effects model and allow both the intercepts and time coefficients to vary across regions. The results, shown in column (4), are consistent with the fixed effects model of column (2): the public and private capltal varlables are Insignificant, half of the intercept dummy varlables are significant, and none of the regional time dummies are significant. However, the addition of the capacity utilization varlable does make a difference. When it is included, the public capltal coefficient is significantly negative, implying that public capital externalities reduce MFP with an elasticity of -.24 . This is a highly Implausible result, and it casts doubt on the usefulness of using an aggregate capacity utilization adjustment.

How do the results of Table 4 accord with the hypothesis tests of the preceding table? The constraints imposed in Table 4 on the public and private capital parameters only restrict them to be equal, and not to be equal to zero as in Table 3. Moreover, Table 3 considers a wider range of parameter restrictions (1.e., on the time varlable). However, with these differences in mind, It is clear that the proceeding up the hypothesis tree in Figure 1 using Table 4 F-statistics produces similar conclusions about the models that the data wants to reject (1.e., some difference in inltial levels, no difference in the growth rates of MFP, and no effect of public capital).

We note, finally, that we tested several variants of the our models. Following Fernald (1992), we carried out an analysis of (9) using deviations from time trend rather than the log-level of varlables in order to control for 
demand fluctuations and to reduce any simultaneous equation blas resulting from the endogenelty of $K$ and $B$. The results of this exercise were similar to the results obtalned using the capacity utilization variable.

We also tested the assumption of perfect competition using a Hall (1988) marginal cost mark-up model. In an imperfectly competitive market where the ratio of price to marginal cost is a constant $\mu$, the income shares of labor and Intermediate input are equal to the true output elasticities divided by $\mu$ (1.e., $\pi_{1 t}^{L}=\varepsilon_{1 t}^{L}, \mu$ and $\left.\pi_{1 t}^{M}=\varepsilon_{1 t}^{M} / \mu\right)$. If capital's share is calculated as a residual so the shares sum to 1 , then it is not difficult to show that Hall's model implles that (9) Becomes

$$
\begin{aligned}
\ln A_{i t}^{S} & =\ln A_{i 0}+\lambda_{i} t+\left[\gamma_{i}+\varepsilon_{i}^{B}\right] \ln B_{i t}+\left[\varepsilon_{1}-1\right] \ln K_{i t} \\
& +(\mu-1)\left[\pi_{i t}^{M} \ln \left(M_{i t} / K_{i t}\right)+\pi_{i t}^{L} \ln \left(L_{i t} / K_{i t}\right)\right] .
\end{aligned}
$$

We estimate this model by including the share welghted log of the intermediate Input-capital and the labor-capital ratios to the models shown in Table 4. As shown in equation ( $9 ")$, the coefficient on this varlable represents an estimate of $(\mu-1)$. Under perfect competition price equals marginal cost, $\mu$ equals 1 , and the coefficlent on $\pi_{1 t}^{M} \ln \left(M_{1 t} / K_{1 t}\right)+\pi_{1 t}^{L} \ln \left(L_{1 t} / K_{1 t}\right)$ will equal zero; If firms have market power then price will exceed marginal cost and this coefficlent will be positlve.

Estimates of different versions of this Hall model are shown in Table 5 . In those specifications where we Include capacity utilization variable, our estimate of $(\mu-1)$ is always positive and significant; in those specifications where we exclude capacity utllization varlable, our estimate of 
$(\mu-1)$ is always Insigniflcant. Estimates of all of the other parameters in Table 5 are quite simllar to the corresponding estimates in Table 4 .

\section{Conclusions}

This paper has proposed a framework for testing three of the leading explanations of comparative reglonal growth based on different predictions about the times paths of technlcal efflciency. While the tests are limited to the manufacturing Industry and not all of the variants of the competing theories are tested, the tests do provide evidence against two of the major competitors. Specifically, the absence of MFP convergence or divergence is not compatible with the predictions of the technological convergence or endogenous growth models. Moreover, an inspection of the trends in output per worker and capital per worker for the 1970-86 and the 1951-86 periods using different output concepts does not offer any encouragement for the capltal-deepening varlant of the convergence hypothesis.

We have also found that the externalities associated with public capltal are, for the most part, not statistically significant and the point estimates of the elastlcity of MFP with respect to public capital in some versions of the model are negative. Of course, this applies only to manufacturing, but it lends little support to the argument that public capital externalities are an important engine of growth. If externalities are not significant in this important sector, where do they play an important role in regional economic development? 
We also find that manufacturing is subject to constant returns to scale at the regional level. This result suggests that agglomeration economies may play only a limited role in regional economic growth.

Our findings suggest that manufacturing industry was open to flows of capital. labor, and technology, and this is more congenlal to the traditional equilibrium approach to location theory than to the other two models which are imported from international growth analysis. The main engine of differential regional manufacturing growth over the perlod $1970-86$ seems to be inter-reglonal flows of capltal and labor, whlle the growth of multifactor productivity is essentially unfform across reglons (although there appears to be some varlation in the inttial levels of efficlency).

Several aspects of our results deserve emphasis in this summing up. First, the statistical results reported above refer to a relatively short, and recent, time perlod: 1970-86. It may well be the case that technological convergence and public capital externalities were important in an earlier stage of U.S. reglonal development. However, our estimates of a limited version of our model for the period 1951-86 (which by necessity could not consider public capital and relled on value added rather than gross output) ylelded virtually the same results. Second, it cannot be emphasized too strongly that we have assumed that the Law of One Price holds. If there is significant reglonal varlation in the deflators used to estimate real output. our results could be dramatically altered.

Third, our finding that public capltal externalities were not an important source of regional manufacturing growth does not mean that public capital formation is irrelevant. It may well have played an essential role in 
facllitating the movement of capltal, labor, and Intermedlate inputs whlch we flnd are the maln sources of differentlal reglonal growth. Furthermore, because the Impact of lumpy Infrastructure projects like the Interstate Highway System may be hlghly non-linear, there may be extended perlods durlng which the average product of publlc capltal is high but its marglnal product Is almost zero. But, even with these caveats, our results are relevant for the question of whether undetected externallties might thus have led governments to supply too little public capltal In recent years. We find no evidence of under-supply in the reglonal manufacturing data. 
As noted by Baumol (1986), the convergence hypothesis has a long tradition and an extensive 11terature. Recent contributions include Dollar and Wolff (1988), De Long (1988), Baumal et. al. (1989), Barro (1991), and Manklw, Romer and Well (1990).

2 The endogenous growth model was developed by Romer (1986), Lucas (1988), and Rebelo (1991). The survey by Sala-1-Martin (1990a, 1990b) provides an extensive description of the maln varlants of the endogenous growth model and their relation to optimal growth theory.

3 Our focus on reglonal manufacturing industry is motivated in part by the importance on manufacturing in the reglonal model developed by Krugman (1991), and also by the fact that data on inputs and output are better for this sector of the economy. However, the narrower Industrlal focus of this paper means that our results are not strictly comparable to those based on broader measures of reglonal output such as total private gross state product.

4 This specification of the public capltal externality assumes that the only source of splllovers in each region is the quantity of public capltal within that region. This reflects the assumption that the highway system of one region gives rise to positive splllovers, but the highways of an adjacent region have no effect at all. Thls is consistent with our interpretation of the region speciflc externalitles as an engine of regionally endogenous growth. However, it is also possible that publlc capital externalitles affect all reglons, in which case the relevant argument of $\mathrm{Al} \cdot \mathrm{l}$ would be total publlc capital, $B_{t}=\Sigma_{1} B_{1 t}$, or a vector of the public capital in all reglons. 
5 It should be noted that the literature on convergence theory has two distinct branches: the one descrlbed above and another in which convergence takes place as a country or region moves to its steady-state rate of growth by capltal deepening. When the production function has the form $q_{t}=k_{t}$, the convergence equation is given by an equation similar to (2):

$\left(2^{\prime}\right) \quad \ln q_{t}-\ln q_{0}=\left(1-(1-\gamma)^{t}\right)\left(\ln \bar{q}-\ln q_{0}\right)$.

where $\gamma=(1-\alpha) \eta$ is the speed of convergence parameter (Holtz-Eakin (1991), following Mank (w, Romer, and Well (1990)). With labor- augmenting technlcal progress at a rate $\lambda$, the steady state values of output and capltal per "raw" worker wlll grow at the rate of technlcal change, and the speed of convergence parameter becomes $\boldsymbol{r}=(1-\alpha)(\eta+\lambda)$. Thls $1 \mathrm{~s}$ the approach taken by Barro and Sala-1-Martin (1991) and Holtz-Eakin (1991), and both studies find a convergence effect within the regions of the U.S. In this interpretation, the older Industrial regions of the U.S. experlenced slower growth than the South and West because the older reglons were further along in the convergence process and closer to their balanced growth paths. This interpretation has been challenged by Blanchard (1991), who demonstrates that the convergence equation ( $\left.2^{\prime}\right)$ can be derlved from the spatlal equilibrium model and shows that the convergence parameter of thelr estimating equation can equally be interpreted as a demand elasticity. We will not attempt an econometric test of (2') in this paper, but wlll comment on 1 ts applicablilty in our section on regional data.

According to BLS data, trucks and autos accounted for approximately 8 percent of the incone accruing to equipment in manufacturing, and thus about one percent of the total income, over the perlod 1949-83, and that communications and electricity generation equipment, which account for about 9 percent of income accruing to equipment, and, again, about one percent of total income. This low share reflects the fact that public capital is mainly an input to the transportation and communication sectors, to public utillties, and to some service industrles, and these sectors pass along their services (and thus the services of public capltal) by selling their output to manufacturing industries. Thus, public capital is at best a marginal contributor to the gross output of many industries. 
This mode of analysis, also termed "sources of growth analysis," was developed by Solow (1957), Kendrick (1961), Denlson (1962), and Jorgenson and Grillches (1967). It is the conceptual basis of the recent studies by the U.S. Bureau of Labor Statistics (1983) and Jorgenson, Gollop, and Fraumenl (1987), and is the framework used in our 1984 and 1991 studies of reglonal economic growth. The sources of growth analysis has, for the most part. ignored the role of public capltal as a source of output growth.

8 All growth rates are the continuous growth rates of the level Solow index numbers.

9 The constancy of these parameters 1mposes restrictions on the underlying technical efficlency function in (1): if, for example, the elasticlty of scale is constant at $\varepsilon$, the production function is homogeneous of degree $\varepsilon$. Note, however, that the multiplicative restrictions on the form of the efficlency function does not impose restrictions on the rest of the technology, $F(\cdot)$. In particular, they do not imply that the production function has the Cobb-Douglas form.

10

An econometric problem that arises when estimating (9) using ordinary least squares should be noted. Private capltal (and possibly public capltal as well), are endogenously determined and thus may be correlated with the error term in the regression. Instrumental variables might be used to avold simultaneous equations blas, but a set of valid regional instruments is hard to find.

11 If the Law of One Price does not hold for manufactured goods within the U.S. market and there is in fact reglonal varlation in output prices, our assumption of one price will overstate real output in those reglons where prices are higher than average. This, in turn, overstates the level index of the Solow residual. If, in addition, the reglonal output prices are changing relative to the average, a blas is introduced into the growth rate of the Solow residual as well.

12 Throughout the paper, we define the Snow Belt as the New England. Middle Atlant1c. East North Central, and West North Central Census divisions. The Sun Belt includes the South Atlant1c, East South Central, West South Central. Mountain, and Paclfic divisions. 
If a 5 percent level of signiflcance is used in the tests of first level of hypotheses $\left(R_{1}, R_{2}\right.$, etc.) then a different level of signiflcance should be used in tests of the jolnt hypotheses. An approximate significance on 20 percent would, for example, be assigned to $R_{1234}$, by the Bonferronl Inequallty (see Savin 1984). 


\section{Blblography}

Aschauer, David A. (1989). "Is Publlc Expendlture Productive?," Journal of Monetary Econom1cs, 23, 177-200.

Aschauer, David A. (1990). "Why is Infrastructure Important?," In Allcla $\mathrm{H}$. Munnell (ed.), Is There a Shortfall in Public Capltal Investment?. Federal Reserve Bank of Boston, Boston, 21-50.

Barro, Robert J. (1990). "Government Spending in a Simple Model of Endogenous Growth," Journal of Polltical Economy, 98, Pt. 2, S103-S125.

Barro, Robert J. (1991). "Economic Growth in a Cross Section of Countries, The Quarterly Journal of Economics, 106, 407-443.

Barro, Robert J. and Xavier Sala-1-Martin (1991). "Convergence Across States and Reglons", Brookings Papers on Economlc Activity. No. 1, 107-158.

Baumol, William J. (1986). "Productivity Growth, Convergence, and Welfare: What the Long Data Show," Amerlcan Economlc Revlew, 76, 1072-1085.

Baumol, Wlll am J., Sue A.B. Blackman, and Edward N. Holff, (1989). Productivity and American Leadershlp: The Long Vlew. The MIT Press, Cambridge Massachusetts.

Berndt, Ernst R. and Bengt Hansson (1992). "Measuring the Contribution of Public Infrastructure Capital in Sweden," The Scandinavian Journal of Economlcs, 94 (supplement), S151-S168.

Blanchard, Ollvier J. (1991). "Comments on 'Convergence Across States and Reglons," Brookings Papers on Economic Activity, No. 1, 159-174.

Caballero, R. and R. Lyons (1990a). "The Role of Externalities in U.S. Manufacturing," National Bureau of Economlc Research Working Paper No. 3033.

Caballero, R. and R. Lyons (1990b). "Internal and External Economies in European Industries," European Economlc Revlew,

Chrlstensen, Laurlts R., Dlane Cummings, and Dale W. Jorgenson (1981). "Relative Productivity Levels, 1947-1973: An International Comparison," European Economic Revlew, 16, 61-94.

De Long, J. Bradford (1988). "Productlvity Growth, Convergence, and Welfare: Comment," American Economic Revlew. 78, 1138-1154.

Denison, Edward F. (1962). The Sources of Economic Growth in the United States and the Alternatives before Us. New York, Committee for Economic Development. 
Denny, Mlchael, Melvyn Fuss, and J.D. May (1981). "Intertemporal Changes in Regional Productivity in Canadian Manufacturing." Canadian Journal of Economics, 14, 390-408.

Diewert, W. Erwin (1976). "Exact and Superlative Index Numbers," Journal of Econometrics, 4, 115-145.

Dowr 1ck, Steve and Duc-Tho Nguyen (1989). "OECD Comparative Economic Growth 1950-85: Catch-up and Convergence," The American Review, 79, 1010-1030.

Garcia-Mila, Teresa and Therese J. McGuire, "The Contribution of Publicly Provided Inputs to States' Economies," Journal of Regional Science. for thcoming.

Hall, Robert E. "The Relation between Price and Marginal Cost in U.S. Industry," Journal of Pol1tical Economy, 96, 921-947.

Holtz-Eakin, Douglas (1991). "Solow and the States: Capital Accumulation. Productivity and Economic Growth," Syracuse University working paper.

Holtz-Eakin. Douglas (1992). "Public Sector Capital and the Productivity Puzzle," Natlonal Bureau of Economic Research Working Paper No. 4144.

Hulten, Charles R. (1973). "Divisia Index Numbers," Econometrica, 41. 1017-1025.

Hulten, Charles R. and Robert M. Schwab (1991). "Public Capital Formation and the Growth of Regional Manufacturing Industries," National Tax Journal, December, 121-134.

Hulten, Charles R. and Robert M. Schwab (1984). "Reglonal Productivity Growth in U.S. Manufacturing: 1951-1978," Amerlcan Economlc Review, 1984, 74, $152-162$.

Jorgenson, Dale W., Frank Gollop and Barbara Fraumeni (1987). Productivity and U.S. Economlc Growth. Harvard University Press, Cambridge.

Jorgenson, Dale W. and Zvi Griliches (1967). "The Explanation of Productivity Change," Revlek of Economic Studies. 34, 249-283.

Jorgenson, Dale W. and Mleko Nishimizu (1978). "U.S. and Japanese Economic Growth, 1952-1874: An International Comparison," The Economic Journal, $88,707-726$.

Kendrick, John, (1961). Productivity Trends in the United States. National Bureau of Economic Research, New York.

Krugman, Paul (1991). "Increasing Returns and Economic Geography," Journal of Political Economy. 99, 483-499.

Krugman. Paul (1993). "On the Relationship Between Trade Theory and Location Theory," Review of International Economics, 1, June, 111-122. 
Lucas, Robert E. Jr. (1988). "On the Mechanlcs of Economlc Development," Journal of Monetary Economics, 22, 3-42.

Mank1w, N. Gregory, David Romer, and David N. Well (1990). "A Contrlbution to the Emplrics of Economic Growth," National Bureau of Economic Research, Cambridge Massachusetts.

Meade, James E. (1952). "External Economles and DIseconomles in a Compet 1 t 1 ve Situation," Economic Journal, 62, 54-67.

Morrison, Catherine J. and Amy Ellen Schwartz, "State Infrastructure and Economic Performance," National Bureau of Economic Research Working Paper No. 3981, Cambridge Massachusetts, January 1992.

Munnell, Allcla H. (1990). "How Does Publlc Infrastructure Affect Reglonal Economic Performance?," in Alicla H. Munnell (ed.), Is There a Shortfall In Public Capltal Investment?. Federal Reserve Bank of Boston, Boston, 69-103.

Rebelo, Sergio T. (1991). "Long-Run Pollcy Analysis and Long-Run Growth," Journal of Polltical Economy. Vol. 99, No. 3, 500-521.

Romer, Paul M. (1986). "Increasing Returns and Long-Run Growth," Journal of Polltical Economy. 94, 1002-1037.

Romer, Paul M. (1990). "Endogenous Technlcal Change," Journal of Polltical Economy, 98, Pt. 2, S71-S102.

Sala-1-Martin, Xavier (1990a). "Lecture Notes on Economic Growth (I): Introduction to the Literature and Neoclassical Models," National Bureau of Economlc Research Working Paper 3563, Cambridge Massachusetts.

Sala-1-Martin, Xavler (1990b). "Lecture Notes on Economic Growth (II): Flve Prototype Models of Endogenous Growth," National Bureau of Economic Research Working Paper 3564, Cambridge Massachusetts.

Savin, N.E. (1984). "Multiple Hypothesis Testing," in Zvi Grillches and Michael D. Intrillgator (eds.), Handbook of Econometrlcs. North Holland. Amsterdaw, 827-880.

Solow, Robert M. (1957). "Technical Change and the Aggregate Production Function," Revlew of Economics and Statistics, 39, 312-320.

U.S. Bureau of Labor Statistics (1983). Irends in Multifactor Productivity 1948-81, Bulletin 2178, United States Government Printing Office, Washington. 
</ref_section> 
Table 1

Sumbry of the Level and Growth Rate of Manufocturing Gross Output $1970-1986$

(U.5. $1970=1.000)$

\begin{tabular}{|c|c|c|c|c|c|c|c|c|c|c|c|c|}
\hline & ME & $m$ & EWC & We & sa & ESC & usc & $n$ & PAC & Total & $\begin{array}{l}\text { Snow } \\
\text { Belt }\end{array}$ & $\sin _{\text {velt }}$ \\
\hline $\begin{array}{l}\text { Gross output } \\
1970 \\
1986 \\
\text { Growth Rete }\end{array}$ & $\begin{array}{l}0.0590 \\
0.0851 \\
0.0229\end{array}$ & $\begin{array}{l}0.1970 \\
0.2106 \\
0.0039\end{array}$ & $\begin{array}{l}0.2767 \\
0.3623 \\
0.0169\end{array}$ & $\begin{array}{l}0.0764 \\
0.1212 \\
0.0289\end{array}$ & $\begin{array}{l}0.1236 \\
0.2201 \\
0.0362\end{array}$ & $\begin{array}{l}0.0573 \\
0.0978 \\
0.0336\end{array}$ & $\begin{array}{l}0.0780 \\
0.1564 \\
0.0635\end{array}$ & $\begin{array}{l}0.0220 \\
0.0628 \\
0.0616\end{array}$ & $\begin{array}{l}0.1094 \\
0.1935 \\
0.0357\end{array}$ & $\begin{array}{l}1.0000 \\
1.4897 \\
0.0269\end{array}$ & $\begin{array}{l}0.6100 \\
0.7792 \\
0.0153\end{array}$ & $\begin{array}{l}0.3900 \\
0.7105 \\
0.0375\end{array}$ \\
\hline $\begin{array}{l}\text { Labor } \\
1970 \\
1986 \\
\text { Growth Rate }\end{array}$ & $\begin{array}{r}0.0773 \\
0.0753 \\
-0.0017\end{array}$ & $\begin{array}{r}0.2205 \\
0.1626 \\
-0.0190\end{array}$ & $\begin{array}{r}0.2620 \\
0.2196 \\
-0.0110\end{array}$ & $\begin{array}{l}0.0633 \\
0.0686 \\
0.0069\end{array}$ & $\begin{array}{l}0.1325 \\
0.1531 \\
0.0099\end{array}$ & $\begin{array}{l}0.0579 \\
0.0628 \\
0.0050\end{array}$ & $\begin{array}{l}0.0618 \\
0.0765 \\
0.0136\end{array}$ & $\begin{array}{l}0.0187 \\
0.0310 \\
0.0316\end{array}$ & $\begin{array}{l}0.1053 \\
0.1353 \\
0.0156\end{array}$ & $\begin{array}{r}1.0000 \\
0.9060 \\
-0.0008\end{array}$ & $\begin{array}{r}0.6227 \\
0.5256 \\
-0.0106\end{array}$ & $\begin{array}{l}0.3767 \\
0.4611 \\
0.0126\end{array}$ \\
\hline $\begin{array}{l}\text { Private Capital } \\
1970 \\
1986 \\
\text { Growth Rate }\end{array}$ & $\begin{array}{l}0.0580 \\
0.0902 \\
0.0275\end{array}$ & $\begin{array}{l}0.1890 \\
0.2210 \\
0.0098\end{array}$ & $\begin{array}{l}0.2877 \\
0.3656 \\
0.0115\end{array}$ & $\begin{array}{l}0.0552 \\
0.1006 \\
0.0376\end{array}$ & $\begin{array}{l}0.1261 \\
0.2122 \\
0.0325\end{array}$ & $\begin{array}{l}0.0597 \\
0.0921 \\
0.0271\end{array}$ & $\begin{array}{l}0.0896 \\
0.1727 \\
0.0609\end{array}$ & $\begin{array}{l}0.0199 \\
0.0658 \\
0.0521\end{array}$ & $\begin{array}{l}0.1136 \\
0.1995 \\
0.0352\end{array}$ & $\begin{array}{l}1.0000 \\
1.4612 \\
0.0266\end{array}$ & $\begin{array}{l}0.5896 \\
0.7571 \\
0.0157\end{array}$ & $\begin{array}{l}0.6106 \\
0.7260 \\
0.0356\end{array}$ \\
\hline $\begin{array}{l}\text { Intermediate in } \\
1970 \\
1986 \\
\text { Growth Rote }\end{array}$ & $\begin{array}{l}0.0506 \\
0.0640 \\
0.0147\end{array}$ & $\begin{array}{r}0.1838 \\
0.1757 \\
-0.0028\end{array}$ & $\begin{array}{l}0.2772 \\
0.3628 \\
0.0133\end{array}$ & $\begin{array}{l}0.0859 \\
0.1206 \\
0.0211\end{array}$ & $\begin{array}{l}0.1258 \\
0.2003 \\
0.0291\end{array}$ & $\begin{array}{l}0.0578 \\
0.0965 \\
0.0308\end{array}$ & $\begin{array}{l}0.0875 \\
0.1677 \\
0.0607\end{array}$ & $\begin{array}{l}0.0265 \\
0.0371 \\
0.0259\end{array}$ & $\begin{array}{l}0.1069 \\
0.1722 \\
0.0298\end{array}$ & $\begin{array}{l}1.0000 \\
1.3749 \\
0.0190\end{array}$ & $\begin{array}{l}0.5976 \\
0.7030 \\
0.0102\end{array}$ & $\begin{array}{l}0.6026 \\
0.6719 \\
0.0320\end{array}$ \\
\hline $\begin{array}{l}\text { Multifactor Pro } \\
1970 \\
1986 \\
\text { Growth Rote }\end{array}$ & $\begin{array}{r}\text { Auctivity } \\
0.9113 \\
1.1639 \\
0.0153\end{array}$ & $\begin{array}{l}0.977 \\
1.1966 \\
0.0128\end{array}$ & $\begin{array}{l}1.0192 \\
1.2869 \\
0.0146\end{array}$ & $\begin{array}{l}1.1095 \\
1.3137 \\
0.0106\end{array}$ & $\begin{array}{l}0.9576 \\
1.2122 \\
0.0167\end{array}$ & $\begin{array}{l}0.9639 \\
1.2285 \\
0.0139\end{array}$ & $\begin{array}{l}1.0226 \\
1.2531 \\
0.0127\end{array}$ & $\begin{array}{l}1.0506 \\
1.2069 \\
0.0087\end{array}$ & $\begin{array}{l}1.0202 \\
1.2285 \\
0.0116\end{array}$ & $\begin{array}{l}1.0000 \\
1.2366 \\
0.0136\end{array}$ & $\begin{array}{l}1.0027 \\
1.2505 \\
0.0138\end{array}$ & $\begin{array}{l}0.9965 \\
1.2251 \\
0.0130\end{array}$ \\
\hline $\begin{array}{l}\text { Labor Product iv } \\
1970 \\
1986 \\
\text { Growth Rate }\end{array}$ & $\begin{array}{l}0.7630 \\
1.1303 \\
0.0266\end{array}$ & $\begin{array}{l}0.8976 \\
1.2948 \\
0.0229\end{array}$ & $\begin{array}{l}1.0561 \\
1.6481 \\
0.0278\end{array}$ & $\begin{array}{l}1.2075 \\
1.721 \\
0.0240\end{array}$ & $\begin{array}{l}0.9315 \\
1.6192 \\
0.0263\end{array}$ & $\begin{array}{l}0.9896 \\
1.5572 \\
0.0283\end{array}$ & $\begin{array}{l}1.2630 \\
2.0664 \\
0.0301\end{array}$ & $\begin{array}{l}1.1726 \\
1.3815 \\
0.0102\end{array}$ & $\begin{array}{l}1.0383 \\
1.6306 \\
0.0200\end{array}$ & $\begin{array}{l}1.0000 \\
1.3096 \\
0.0257\end{array}$ & $\begin{array}{l}0.9785 \\
1.6831 \\
0.0259\end{array}$ & $\begin{array}{l}1.0353 \\
1.5609 \\
0.0269\end{array}$ \\
\hline $\begin{array}{l}\text { Copital Labor R } \\
1970 \\
1988 \\
\text { Growth Rate }\end{array}$ & $\begin{array}{l}0.7510 \\
1.1984 \\
0.0292\end{array}$ & $\begin{array}{l}0.8570 \\
1.3592 \\
0.0280\end{array}$ & $\begin{array}{l}1.0961 \\
1.5719 \\
0.0226\end{array}$ & $\begin{array}{l}0.8726 \\
1.4675 \\
0.0325\end{array}$ & $\begin{array}{l}0.9522 \\
1.3687 \\
0.0227\end{array}$ & $\begin{array}{l}1.0307 \\
1.6669 \\
0.0221\end{array}$ & $\begin{array}{l}1.6561 \\
2.2570 \\
0.0275\end{array}$ & $\begin{array}{l}1.0622 \\
1.6790 \\
0.0207\end{array}$ & $\begin{array}{l}1.0780 \\
1.6745 \\
0.0198\end{array}$ & $\begin{array}{l}1.0000 \\
1.5010 \\
0.0254\end{array}$ & $\begin{array}{l}0.9604 \\
1.6611 \\
0.0263\end{array}$ & $\begin{array}{l}1.0099 \\
1.5701 \\
0.0228\end{array}$ \\
\hline $\begin{array}{l}\text { Public Copleal } \\
1970 \\
1986 \\
\text { Growth Rote }\end{array}$ & $\begin{array}{l}0.0516 \\
0.0645 \\
0.0139\end{array}$ & $\begin{array}{l}0.1820 \\
0.2268 \\
0.0130\end{array}$ & $\begin{array}{l}0.1893 \\
0.2219 \\
0.0099\end{array}$ & $\begin{array}{l}0.0067 \\
0.1119 \\
0.0176\end{array}$ & $\begin{array}{l}0.1235 \\
0.1969 \\
0.0285\end{array}$ & $\begin{array}{l}0.0620 \\
0.0793 \\
0.0156\end{array}$ & $\begin{array}{l}0.0920 \\
0.1364 \\
0.0267\end{array}$ & $\begin{array}{l}0.0497 \\
0.0816 \\
0.0310\end{array}$ & $\begin{array}{l}0.1652 \\
0.1959 \\
0.0106\end{array}$ & $\begin{array}{l}1.0000 \\
1.3132 \\
0.0170\end{array}$ & $\begin{array}{l}0.5076 \\
0.6251 \\
0.0430\end{array}$ & $\begin{array}{l}0.4926 \\
0.6801 \\
0.0209\end{array}$ \\
\hline
\end{tabular}

ME - New England, MA - Middle Atlentic, EMC = East North Central. WwC = West Worth Central, SA = South Atlentic, ESC = Eest South Central, usC = West South Central, M = Mountain, PAC = Pacific 
Toble 2

Sumbery of the Growth Rate of Manufacturing Value Added

1951.1986

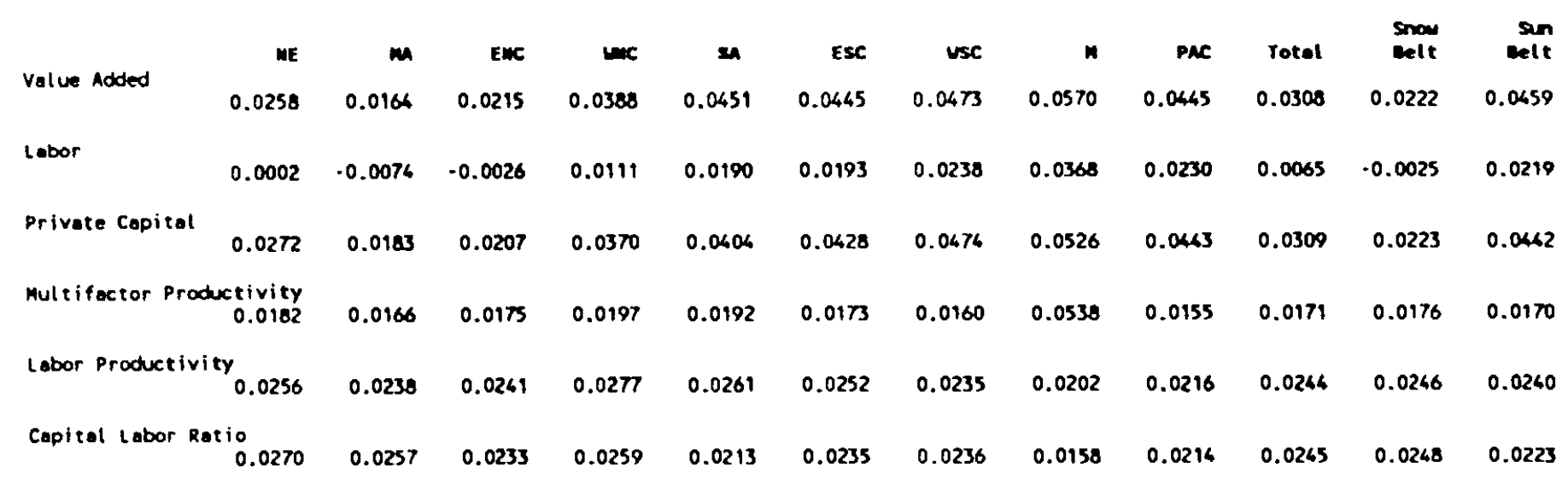

WE = Wew England, MA = Middle Atlentic, EWC = Eost Worth Centrol, wC = West Worth Centrol, SA = South Atlentic, ESC = Eost South Centrol, USC = West South Centrol, M = Mountoin, PAC = Pocific 
Table 3

Error sums of sqaures and F statistics

\begin{tabular}{|c|c|c|c|}
\hline Hypothes io & Error sum of squares & $\begin{array}{c}\text { Reatrictione Relative } \\
\text { to } R_{0}\end{array}$ & $\begin{array}{c}\text { F statistic Relative } \\
\text { to Ro }\end{array}$ \\
\hline$R_{0}$ & .14727 & .. & .. \\
\hline$R_{1}$ & .15436 & 8 & $\quad 0.7061$ \\
\hline $\mathbf{R}_{2}$ & .16030 & 8 & 1.2960 \\
\hline $\mathbf{R}_{3}$ & .16102 & 9 & 1.2138 \\
\hline$R_{4}$ & .16057 & 9 & 1.8802 \\
\hline$R_{12}$ & .17119 & 16 & 1.1877 \\
\hline$R_{: 3}$ & $.179 \pi$ & 17 & 1.5180 \\
\hline$R_{14}$ & .17918 & 17 & 1.6912 \\
\hline$R_{23}$ & .17415 & 17 & 1.2562 \\
\hline$R_{24}$ & .18093 & 17 & 1.5730 \\
\hline$R_{34}$ & .18118 & 18 & 1.6967 \\
\hline$R_{123}$ & .19732 & 25 & 1.5905 \\
\hline$R_{124}$ & .19653 & 25 & 1.5654 \\
\hline$R_{234}$ & .31317 & 26 & 5.0693 \\
\hline$R_{234}$ & .19872 & 26 & 1.5721 \\
\hline$R_{1234}$ & .58580 & 34 & 90.2469 \\
\hline
\end{tabular}


Table 4

Parameter Estimates of Alternotive Restricted Models

\begin{tabular}{|c|c|c|c|c|c|c|c|c|}
\hline & (1) & (2) & (3) & (6) & (5) & (6) & (7) & (8) \\
\hline Intercept & $\begin{array}{r}0.102214 \\
(3.988) \\
\end{array}$ & $\begin{array}{r}-0.315016 \\
(1.681) \\
\end{array}$ & $\begin{array}{r}0.126697 \\
(3.533) \\
\end{array}$ & $\begin{array}{r}-0.060555 \\
(2.037) \\
\end{array}$ & $\begin{array}{r}-0.378122 \\
(3.880) \\
\end{array}$ & $\begin{array}{r}-0.910440 \\
(5.912) \\
\end{array}$ & $\begin{array}{r}-0.351968 \\
(4.979) \\
\end{array}$ & $\begin{array}{r}1.62213 \\
(5.866) \\
\end{array}$ \\
\hline$m$ & $\cdot-$ & $\begin{array}{r}0.176645 \\
(2.133) \\
\end{array}$ & $\cdots$ & $\begin{array}{r}0.361255 \\
(2.504) \\
\end{array}$ & $\cdots$ & $\begin{array}{r}0.223457 \\
(3.579) \\
\end{array}$ & -. & $\begin{array}{r}0.676261 \\
(4.560) \\
\end{array}$ \\
\hline ENC & $\cdots$ & $\begin{array}{r}0.245769 \\
(3.015) \\
\end{array}$ & $\cdots$ & $\begin{array}{r}0.623950 \\
(2.729) \\
\end{array}$ & $\cdots$ & $\begin{array}{r}0.283020 \\
(6.558) \\
\end{array}$ & $\cdots$ & $\begin{array}{r}0.522270 \\
(6.653) \\
\end{array}$ \\
\hline wne & $\cdots$ & $\begin{array}{r}0.200081 \\
(5.137) \\
\end{array}$ & $\because$ & $\begin{array}{r}0.278372 \\
(6.846) \\
\end{array}$ & $\cdots$ & $\begin{array}{r}0.227019 \\
(7.635) \\
\end{array}$ & $\cdots$ & $\begin{array}{r}0.335459 \\
(8.066) \\
\end{array}$ \\
\hline SA & $\cdots$ & $\begin{array}{r}0.120506 \\
(1.911) \\
\end{array}$ & $\because$ & $\begin{array}{r}0.215552 \\
(2.253) \\
\end{array}$ & $\cdot$ & $\begin{array}{r}0.156855 \\
(3.263) \\
\end{array}$ & $\cdots$ & $\begin{array}{r}0.288187 \\
(4.163) \\
\end{array}$ \\
\hline ESC & $\cdots$ & $\begin{array}{r}0.087153 \\
(5.080) \\
\end{array}$ & $-\cdot$ & $\begin{array}{r}0.127440 \\
(4.225) \\
\end{array}$ & $\cdots$ & $\begin{array}{r}0.096803 \\
(7.266) \\
\end{array}$ & $\cdots$ & $\begin{array}{r}0.140696 \\
(6.466) \\
\end{array}$ \\
\hline usc & $\because$ & $\begin{array}{r}0.195922 \\
(4.797) \\
\end{array}$ & $\cdots$ & $\begin{array}{r}0.245046 \\
(4.018) \\
\end{array}$ & $\cdots$ & $\begin{array}{r}0.215640 \\
(6.930) \\
\end{array}$ & -. & $\begin{array}{r}0.280537 \\
(6.562) \\
\end{array}$ \\
\hline MT & $\cdots$ & $\begin{array}{r}0.060219 \\
(1.591) \\
\end{array}$ & $\cdots$ & $\begin{array}{r}0.065613 \\
(0.965) \\
\end{array}$ & $\cdots$ & $\begin{array}{r}0.070654 \\
(2.728) \\
\end{array}$ & $\cdots$ & $\begin{array}{r}0.081865 \\
(1.636) \\
\end{array}$ \\
\hline PAC & $\cdots$ & $\begin{array}{r}0.191201 \\
(2.653) \\
\end{array}$ & $\cdot \cdot$ & $\begin{array}{r}0.338488 \\
(2.787) \\
\end{array}$ & $\cdots$ & $\begin{array}{r}0.237179 \\
(4.313) \\
\end{array}$ & $\cdots$ & $\begin{array}{r}0.456201 \\
(5.155) \\
\end{array}$ \\
\hline Time & $\begin{array}{r}0.008445 \\
(0.241) \\
\end{array}$ & $\begin{array}{r}0.010567 \\
(7.225) \\
\end{array}$ & $\begin{array}{r}0.006316 \\
(3.735) \\
\end{array}$ & $\begin{array}{r}0.015121 \\
(5.460) \\
\end{array}$ & $\begin{array}{r}0.009906 \\
(9.993) \\
\end{array}$ & $\begin{array}{l}0.012336 \\
(10.959) \\
\end{array}$ & $\begin{array}{r}0.007692 \\
(5.225) \\
\end{array}$ & $\begin{array}{r}0.016974 \\
(8.461) \\
\end{array}$ \\
\hline Time-mA & $\cdots$ & $\cdots$ & $\begin{array}{r}-0.002131 \\
(0.859) \\
\end{array}$ & $\begin{array}{r}-0.005766 \\
(1.976) \\
\end{array}$ & $\cdots$ & -. & $\begin{array}{r}-0.001712 \\
(0.816) \\
\end{array}$ & $\begin{array}{r}0.005071 \\
(2.612) \\
\end{array}$ \\
\hline Time=ENC & $\cdots$ & $\cdots$ & $\begin{array}{r}0.007321 \\
(3.439) \\
\end{array}$ & $\begin{array}{r}-0.003467 \\
(1.235) \\
\end{array}$ & $\cdots$ & $\cdots$ & $\begin{array}{r}0.007512 \\
(6.163) \\
\end{array}$ & $\begin{array}{r}-0.003097 \\
(1.532) \\
\end{array}$ \\
\hline Time*wanc & $\cdots$ & $\cdots$ & $\begin{array}{r}0.008035 \\
(4.117) \\
\end{array}$ & $\begin{array}{r}-0.003878 \\
(1.665) \\
\end{array}$ & $\cdots$ & $\cdots$ & $\begin{array}{r}0.000342 \\
(5.041) \\
\end{array}$ & $\begin{array}{r}-0.003 \times 97 \\
(1.033) \\
\end{array}$ \\
\hline $\operatorname{Tim} \times \sin ^{\prime}$ & $\cdots$ & $\because$ & $\begin{array}{r}0.002247 \\
(1.058) \\
\end{array}$ & $\begin{array}{r}0.001049 \\
(0.332) \\
\end{array}$ & $\cdots$ & $\cdots$ & $\begin{array}{r}0.001937 \\
(1.076) \\
\end{array}$ & $\begin{array}{r}0.003106 \\
(1.359) \\
\end{array}$ \\
\hline TIme*ESC & $\cdots$ & $\cdots$ & $\begin{array}{r}0.004258 \\
(2.824) \\
\end{array}$ & $\begin{array}{r}-0.002564 \\
(0.987) \\
\end{array}$ & $\cdots$ & $\cdots$ & $\begin{array}{r}0.006339 \\
(3.396) \\
\end{array}$ & $\begin{array}{r}-0.002015 \\
(1.076) \\
\end{array}$ \\
\hline
\end{tabular}




\begin{tabular}{|c|c|c|c|c|c|c|c|c|}
\hline Time*usc & .. & $\cdots$ & $\begin{array}{r}0.009938 \\
(5.925) \\
\end{array}$ & $\begin{array}{r}0.002267 \\
(0.746) \\
\end{array}$ & .. & .. & $\begin{array}{r}0.010056 \\
(7.073)\end{array}$ & $\begin{array}{r}0.003223 \\
(1.472)\end{array}$ \\
\hline Tíme*Mt & .. & $\cdots$ & $\begin{array}{r}-0.000853 \\
(0.393) \\
\end{array}$ & $\begin{array}{r}-0.002950 \\
(0.867) \\
\end{array}$ & .. & .. & $\begin{array}{r}-0.000488 \\
(0.266)\end{array}$ & $\begin{array}{r}-0.001322 \\
(0.538)\end{array}$ \\
\hline Pime*PAC & - & $\cdots$ & $\begin{array}{r}0.001227 \\
(0.520) \\
\end{array}$ & $\begin{array}{r}-0.004016 \\
(1.515) \\
\end{array}$ & -. & .. & $\begin{array}{r}0.001630 \\
(0.816) \\
\end{array}$ & $\begin{array}{r}-0.006545 \\
(2.379)\end{array}$ \\
\hline $\begin{array}{l}\text { In Public } \\
\text { Capital }\end{array}$ & $\begin{array}{r}0.081696 \\
(3.526)\end{array}$ & $\begin{array}{r}-0.036604 \\
(0.472)\end{array}$ & $\begin{array}{r}0.158639 \\
(4.706)\end{array}$ & $\begin{array}{r}-0.117309 \\
(1.036)\end{array}$ & $\begin{array}{r}0.079613 \\
(3.7111)\end{array}$ & $\begin{array}{r}-0.094269 \\
(1.590)\end{array}$ & $\begin{array}{r}0.150372 \\
(5.263)\end{array}$ & $\begin{array}{r}-0.246361 \\
(2.961)\end{array}$ \\
\hline $\begin{array}{l}\text { Ln Private } \\
\text { Capl tal }\end{array}$ & $\begin{array}{r}-0.064530 \\
(2.606)\end{array}$ & $\begin{array}{r}-0.046562 \\
(1.029)\end{array}$ & $\begin{array}{r}-0.105826 \\
(4.556)\end{array}$ & $\begin{array}{r}-0.076725 \\
(1.096)\end{array}$ & $\begin{array}{r}-0.043009 \\
(2.726)\end{array}$ & $\begin{array}{r}-0.026187 \\
(0.702)\end{array}$ & $\begin{array}{r}-0.100638 \\
(5.109)\end{array}$ & $\begin{array}{r}-0.060135 \\
(0.793)\end{array}$ \\
\hline $\begin{array}{l}\text { Copocity } \\
\text { Utilization }\end{array}$ & $\cdots$ & $\cdots$ & -. & $\cdots$ & $\begin{array}{r}0.005806 \\
(5.082) \\
\end{array}$ & $\begin{array}{l}0.005961 \\
(10.191)\end{array}$ & $\begin{array}{r}0.005731 \\
(7.501) \\
\end{array}$ & $\begin{array}{l}0.006007 \\
(11.150) \\
\end{array}$ \\
\hline$R^{2}$ & .3661 & .7609 & .6801 & .7906 & .4603 & .8673 & .7718 & .0922 \\
\hline SSE & $.534 \pi$ & .19696 & .26907 & .17668 & .45531 & .11192 & .19850 & .09098 \\
\hline F-gtatistic & 16.8480 & 1.7182 & 0.7609 & $-\cdot$ & 33.0372 & 3.7976 & 18.4115 & .. \\
\hline
\end{tabular}

t statistics in porentheses 
Table 5

Parameter Estimates of Hall Price Marginal Cost Model

\begin{tabular}{|c|c|c|c|c|c|c|c|c|}
\hline & (1) & (2) & (3) & (6) & (5) & (6) & (7) & (8) \\
\hline Intercept & $\begin{array}{r}0.111867 \\
(4.651) \\
\end{array}$ & $\begin{array}{r}-0.366781 \\
(2.061) \\
\end{array}$ & $\begin{array}{r}0.131676 \\
(3.766) \\
\end{array}$ & $\begin{array}{r}-0.501104 \\
(1.606) \\
\end{array}$ & $\begin{array}{r}-0.287737 \\
(2.099) \\
\end{array}$ & $\begin{array}{r}0.89163 \\
(5.803) \\
\end{array}$ & $\begin{array}{r}-0.332772 \\
(6.506) \\
\end{array}$ & $\begin{array}{r}-1.435805 \\
(5.661) \\
\end{array}$ \\
\hline MA & $\cdots$ & $\begin{array}{r}0.190808 \\
(2.556) \\
\end{array}$ & $\cdots$ & $\begin{array}{r}0.296728 \\
(2.137) \\
\end{array}$ & $\cdots$ & $\begin{array}{r}0.228430 \\
(3.673) \\
\end{array}$ & $\cdots$ & $\begin{array}{r}0.480016 \\
(4.497) \\
\end{array}$ \\
\hline ENC & $\cdots$ & $\begin{array}{r}.280031 \\
(3.615) \\
\end{array}$ & $\cdots$ & $\begin{array}{r}0.360705 \\
(2.417) \\
\end{array}$ & $\cdots$ & $\begin{array}{r}0.292267 \\
(4.710) \\
\end{array}$ & $\cdots$ & $\begin{array}{r}0.525848 \\
(6.602) \\
\end{array}$ \\
\hline WNC & $\cdots$ & $\begin{array}{r}0.166376 \\
(6.406) \\
\end{array}$ & $\cdots$ & $\begin{array}{r}0.222000 \\
(3.903) \\
\end{array}$ & $\cdots$ & $\begin{array}{r}0.216300 \\
(6.997) \\
\end{array}$ & $\cdots$ & $\begin{array}{r}0.338376 \\
(7.582) \\
\end{array}$ \\
\hline SA & $\cdots$ & $\begin{array}{r}0.136925 \\
(2.287) \\
\end{array}$ & $\cdots$ & $\begin{array}{r}0.184615 \\
(2.013) \\
\end{array}$ & $\cdots$ & $\begin{array}{r}0.160066 \\
(3.346) \\
\end{array}$ & $\cdots$ & $\begin{array}{r}0.290169 \\
(4.130) \\
\end{array}$ \\
\hline ESC & $\cdots$ & $\begin{array}{r}0.091609 \\
(5.638) \\
\end{array}$ & $\cdots$ & $\begin{array}{r}0.166818 \\
(5.018) \\
\end{array}$ & $\cdots$ & $\begin{array}{r}0.095827 \\
(7.375) \\
\end{array}$ & $\cdots$ & $\begin{array}{r}0.139976 \\
(6.316) \\
\end{array}$ \\
\hline usc & $\cdots$ & $\begin{array}{r}0.215901 \\
(5.538) \\
\end{array}$ & $\cdots$ & $\begin{array}{r}0.271294 \\
(4.626) \\
\end{array}$ & $\cdots$ & $\begin{array}{r}0.220908 \\
(7.090) \\
\end{array}$ & $\cdots$ & $\begin{array}{r}0.287790 \\
(6.675) \\
\end{array}$ \\
\hline MT & $\cdots$ & $\begin{array}{r}0.065067 \\
(1.016)\end{array}$ & $\cdots$ & $\begin{array}{r}0.119396 \\
(1.760)\end{array}$ & $\cdots$ & $\begin{array}{r}0.079136 \\
(2.759)\end{array}$ & $\cdots$ & $\begin{array}{r}0.079699 \\
(1.547)\end{array}$ \\
\hline PAC & $\cdots$ & $\begin{array}{r}0.216643 \\
(3.160) \\
\end{array}$ & $\because$ & $\begin{array}{r}0.316981 \\
(2.712) \\
\end{array}$ & $\cdots$ & $\begin{array}{r}0.262739 \\
(6.620) \\
\end{array}$ & $\cdots$ & $\begin{array}{r}0.656220 \\
(5.122) \\
\end{array}$ \\
\hline$T / m e$ & $\begin{array}{r}0.011850 \\
(9.893)\end{array}$ & $\begin{array}{r}0.016131 \\
(8.063)\end{array}$ & $\begin{array}{r}0.008220 \\
(4.575)\end{array}$ & $\begin{array}{r}0.019052 \\
(6.602)\end{array}$ & $\begin{array}{l}0.012376 \\
(10.856)\end{array}$ & $\begin{array}{l}0.013396 \\
(10.263)\end{array}$ & $\begin{array}{r}0.006034 \\
(5.162)\end{array}$ & $\begin{array}{r}0.016821 \\
(7.749)\end{array}$ \\
\hline Time"kA & $\cdots$ & $\cdots$ & $\begin{array}{r}-0.001958 \\
(0.806) \\
\end{array}$ & $\begin{array}{r}-0.006065 \\
(2.169) \\
\end{array}$ & $\cdots$ & $\cdots$ & $\begin{array}{r}-0.0016 \pi \\
(0.796) \\
\end{array}$ & $\begin{array}{r}-0.005053 \\
(2.392) \\
\end{array}$ \\
\hline Time"ENC & $\cdots$ & $\cdots$ & $\begin{array}{r}0.007331 \\
(3.516) \\
\end{array}$ & $\begin{array}{r}-0.004680 \\
(1.663) \\
\end{array}$ & $\cdots$ & $\cdots$ & $\begin{array}{r}0.00 \pi 508 \\
(4.158) \\
\end{array}$ & $\begin{array}{r}-0.003050 \\
(1.692) \\
\end{array}$ \\
\hline Time"unc & $\cdots$ & $\cdot \cdot$ & $\begin{array}{r}0.006203 \\
(3.052) \\
\end{array}$ & $\begin{array}{r}-0.004394 \\
(1.735) \\
\end{array}$ & $\cdots$ & $\cdots$ & $\begin{array}{r}0.007760 \\
(6.376) \\
\end{array}$ & $\begin{array}{r}0.003672 \\
(1.009) \\
\end{array}$ \\
\hline Time*SA & $\cdots$ & $\cdots$ & $\begin{array}{r}-0.002691 \\
(1.197) \\
\end{array}$ & $\begin{array}{r}-0.001665 \\
(0.536) \\
\end{array}$ & $\cdots$ & $\cdots$ & $\begin{array}{r}-0.002023 \\
(1.122) \\
\end{array}$ & $\begin{array}{r}0.003261 \\
(1.348) \\
\end{array}$ \\
\hline TIme*ESC & $\cdot \cdot$ & $\cdots$ & $\begin{array}{r}0.004061 \\
(2.748) \\
\end{array}$ & $\begin{array}{r}-0.005407 \\
(2.004) \\
\end{array}$ & $\cdots$ & $\cdots$ & $\begin{array}{r}0.004276 \\
(3.339) \\
\end{array}$ & $\begin{array}{r}-0.001880 \\
(0.066) \\
\end{array}$ \\
\hline
\end{tabular}




\begin{tabular}{|c|c|c|c|c|c|c|c|c|}
\hline rime*usC & $\cdots$ & $\cdots$ & $\begin{array}{r}0.009572 \\
(5.807) \\
\end{array}$ & $\begin{array}{r}0.003909 \\
(1.171) \\
\end{array}$ & .. & -. & $\begin{array}{r}0.009939 \\
(6.957) \\
\end{array}$ & $\begin{array}{r}0.003697 \\
(1.327) \\
\end{array}$ \\
\hline T I Ime*Mt & $\cdots$ & -. & $\begin{array}{r}0.000358 \\
(0.165)\end{array}$ & $\begin{array}{r}-0.005130 \\
(1.555)\end{array}$ & -. & -. & $\begin{array}{r}-0.000130 \\
(0.069) \\
\end{array}$ & $\begin{array}{r}-0.001216 \\
(0.480)\end{array}$ \\
\hline Time"PAC & -. & -. & $\begin{array}{r}0.001595 \\
(0.609) \\
\end{array}$ & $\begin{array}{r}-0.006534 \\
(2.495) \\
\end{array}$ & -. & $\cdot \cdot$ & $\begin{array}{r}0.001729 \\
(0.062) \\
\end{array}$ & $\begin{array}{r}-0.006661 \\
(2.227) \\
\end{array}$ \\
\hline $\begin{array}{l}I_{M} \ln (M / K) \\
T_{L} \ln (L / K)\end{array}$ & $\begin{array}{r}.0260899 \\
(4.737)\end{array}$ & $\begin{array}{c}0.225726 \\
(4.139)\end{array}$ & $\begin{array}{r}0.166699 \\
(2.652)\end{array}$ & $\begin{array}{l}.247597 \\
(3.732)\end{array}$ & $\begin{array}{r}0.208365 \\
(3.893)\end{array}$ & $\begin{array}{c}0.073753 \\
(1.579)\end{array}$ & $\begin{array}{r}0.044649 \\
(0.859)\end{array}$ & $\begin{array}{r}-0.010626 \\
(0.188)\end{array}$ \\
\hline $\begin{array}{l}\text { In Public } \\
\text { Copitel }\end{array}$ & $\begin{array}{r}0.078704 \\
(3.632)\end{array}$ & $\begin{array}{r}-0.062892 \\
(0.583)\end{array}$ & $\begin{array}{r}0.150655 \\
(4.562)\end{array}$ & $\begin{array}{r}-0.083582 \\
(0.769)\end{array}$ & $\begin{array}{r}0.077584 \\
(3.784)\end{array}$ & $\begin{array}{r}-0.092860 \\
(1.5 \pi 5)\end{array}$ & $\begin{array}{r}0.168217 \\
(5.166)\end{array}$ & $\begin{array}{r}-0.266007 \\
(2.961)\end{array}$ \\
\hline $\begin{array}{l}\text { In Private } \\
\text { Copitel }\end{array}$ & $\begin{array}{r}-0.032747 \\
(2.026) \\
\end{array}$ & $\begin{array}{r}-0.052971 \\
(1.235) \\
\end{array}$ & $\begin{array}{r}-0.093573 \\
(4.032) \\
\end{array}$ & $\begin{array}{r}-0.064749 \\
(0.663) \\
\end{array}$ & $\begin{array}{r}-0.033935 \\
(2.218) \\
\end{array}$ & $\begin{array}{r}-0.027622 \\
(0.806) \\
\end{array}$ & $\begin{array}{r}-0.097066 \\
(6.827) \\
\end{array}$ & $\begin{array}{r}0.061188 \\
(0.806) \\
\end{array}$ \\
\hline $\begin{array}{l}\text { Copocity } \\
\text { Utillizetion }\end{array}$ & .. & -. & $\cdots$ & .. & $\begin{array}{r}0.004806 \\
(4.287) \\
\end{array}$ & $\begin{array}{c}0.005603 \\
(8.977) \\
\end{array}$ & $\begin{array}{r}0.005520 \\
(6.901) \\
\end{array}$ & $\begin{array}{r}0.006160 \\
(9.959) \\
\end{array}$ \\
\hline$n^{2}$ & .6496 & .7941 & .6954 & .8106 & .5100 & .8697 & .7732 & .8922 \\
\hline SSE & .46436 & .17360 & .25696 & .15982 & $.612 \pi$ & .10996 & .19139 & .00096 \\
\hline F-statistic & 16.2206 & 1.2053 & 9.0718 & $\cdots$ & 28.9586 & 3.6161 & 18.0759 & .. \\
\hline
\end{tabular}

t statistics in parentheses 